\title{
Study of Eco-Tourism in Marine Tourism Area Based on Community (case study: Iboih Beach)
}

\author{
Mohammed Nawawiy Loebis ${ }^{1}$, Imam Faisal Pane ${ }^{2}$, Rizka Chairini ${ }^{3}$ \\ Department of Architecture, Faculty of Engineering, Universitas Sumatera Utara, Padang Bulan, Medan 20155 \\ Indonesia. \\ Laboratory History, Theory and Criticsm of Architecture, Departement, Padang Bulan, Medan 20155 Indonesia. \\ Email: imam.faisal@usu.ac.id
}

\begin{abstract}
Iboih Beach is one of the nautical tourism sites located in the city of Sabang. Is one of the marine tourism sites that began to be developed into Eco-tourism. The purpose of this research is very suitable to study the community to tourism on the beach based for marine tourism can be more developed. The benefits of tourism in Iboih beach will be optimally impacted positively and should be felt by the community. To find objective society thinking, researchers used the descriptive method with quantitative approach. The results of this study indicate the existence of public interest to tourism on the Iboih beach already community-based in economic aspects. This can be seen through the economic aspect that is influenced by the business opportunity in the field of tourism to the family income with sig.0,154 - 0,000; the improvement of regional economic quality with the value of sig.0,000-0,000; the maximum profit with the sig.0.110-0,000; and promising income with sig.0.128-0,000, and among those most closely related are aspects of regional economic quality because the significance value is an average of 0,000 . Where the results are stated smaller than 0.05 then the conclusion the smaller the significant value the more related.
\end{abstract}

Keywords: Eco-tourism; Community Based Tourism; Iboih Beach.

\section{INTRODUCTION}

Indonesia is an archipelago rich in attractions that spread from Sabang to Merauke. Tourism that has been developed in various parts of the world because it can increase foreign exchange income for the interests of the country associated with natural resources and varied potential.The increasing of tourism sector is an important development program, also, to increase revenues as well as the promotion of the existence of the nation, both regarding culture, culinary and historical places (Pane, 2016).

Natural resources are diverse cultural, natural and artificial has a characteristic that is very supportive of world tourism (Ferdinandus, 2014). The industry in tourism can provide benefits in economic and social aspects. This is what constitutes the tourism sector becomes an important thing in the development in an area (Diniz et.al, 2014). Indonesia as an archipelagic country with very supportive natural resources, and has a high tourism potential.

Sabang is one of the cities in Aceh, Indonesia. The city is an archipelago, located on the north side of the island of Sumatra. The city is $153 \mathrm{~km}$, consisting of five islands Weh island, klah island, Seulako island, the Island of Rubiah and Rondo island, with the island Weh as the largest island. As is known, Sabang is a potential region in the development of world tourism. Sabang region as the beginning of the boundary or the most end of the island of Sumatra and also often referred to as Kilometer Zero (Zalikha, 2015). In Sabang area master plan 2007-2021 has been established tourist areas that will be a priority in the development of Sabang tourism area within 5 years to come is a marine tourism area one of them in Iboih. Iboih area is a marine tourism destination that presents the underwater scenery is very beautiful. This scenery can be enjoyed by diving or by boarding a boat with a glass base that has been available there (Maulidasari et.al, 2015). The uniqueness that is sold as the main attraction for tourists to come to Sabang, especially the island of Iboih with natural scenery and marine tourism Iboih beach, which is not found in other areas of blue ocean, white sand, and the beauty of coral reefs and fish diverse. Exploiting natural beauty under the sea in Iboih can be continued to the island of Rubiah. In addition to the underwater scenery, the tourism potential is managed in from the island of Iboih, the potential of this tourism is an opportunity to attract world tourist visits with all 
the facilities of international scale (Maulidasari et.al, 2015).

The high activity of tourist visit in Iboih Beach can certainly give negative impact to the environment, therefore, Iboih Beach is one of the marine tourism sites that began to be developed into eco-tourism (eco-tourism) (Aswita et.al, 2015). That's why research on community-based tourism development in Iboih Beach, Sabang needs to be done.

In this study, researchers will identify community involvement in tourism development in Iboih Beach, Sabang. Prior to conducting research, researchers first conducted a study of literature related to tourism, tourism development and community-based tourism (Comunity Based Tourism) as a basis for conducting research. With this research, the researcher concludes how the condition of ecotourism development in marine tourism based on the community in Iboih Beach, Sabang.

\section{TOURISM}

A journey can be called a travel trip if someone travels outside his area to see and discover something unique. Uniqueness is meant here is something that is seen is; In contrast to those in the region, It has historical value and meaning, and something unique that should please the traveler (Zalikha, 2015). Tourism has many benefits that not only focus on tourists but also benefit the community. Tourism is an aspect that has a major impact on the economy that can affect regional and even national development (Goh, 2015 \& Diniz et.al, 2014). Tourism not only provides a new experience for tourists but also can affect the economic, social and sustainable development (Muhammad, 2012). Already a worthy thing in tourism, one of the most important things is the satisfaction of the tourists because if they are satisfied they will come back. And on the other hand, they will be a potential marketing tool (Ginting \& Wahid, 2015). Tourism is interesting and educate and provide a comfortable atmosphere is a major consideration of tourists in deciding to visit and return to the place (Oktaviani \& Suryana, 2006).

\section{ECOTOURISM}

Understanding of ecotourism experienced understanding from time to time (Fandeli \& Mukhlison, 2000). But eco-tourism can be interpreted as a form of tourism that is responsible for the preservation of an unspoiled area, provide economic benefits and maintain cultural integrity for the community. This ecotourism is very precise and efficient This integrity and authenticity of ecosystems in anunspoiled area. Even with eco-tourism, nature conservation can be improved in quality. Ecotourism is an activity that utilizes natural resources in the form of tourism aimed at education, research and conservation of the environment and aims to improve the economy of society and state (Aswita et.al, 2015). Ecotourism as a sustainable development tool 2 and provides long-term social, environmental and economic benefits and is an appropriate priority in the country's economic development (Barkauskiene \& Vytautas, 2013).

Marine Ecotourism is a form of tourism that is managed with a sustainable approach, such as; Natural management is directed to the sustainability of coastal and marine resources, cultural management directed towards the welfare of coastal communities, conservation activities directed to maintain the sustainability of sustainable resource utilization (Tuwo, 2011). The activities undertook Ecotourism on marine tourism oriented to water, namely; Swimming, sailing by boat, diving, snorkeling, fishing, and beach tours.

\section{OBJECT AND ATtractions}

Marine tourism is tourism that many associated with lakes, beaches and sea (Pendit, 1994). Marine tourism is a tourism activity that uses the potential of the beach (water) as the carrying capacity of marine tourism activities. Potential and tourist attraction is one of the factors in tourism development. Tourism potential is a variety of resources contained in a certain area that can be developed into a tourist attraction that is used for economic interests while maintaining other aspects (Pendit, 2002). The potential of tourism according to (Yoeti, 1983). "The potential of tourism is everything that is in the tourist destination, and is an attraction for people to come to visit the place." Based on this research, the component of tourist attraction used is based on the theory (Jaafar et.al, 2015) which states that the component of tourist attraction is based on three components, namely attraction (attraction), access (accessibility), tourism facilities (amenities).

\section{COMMUNITY BASED TOURISM}

Tourism is an industry that can not be predicted will have a trend what in the future. 
The movement within the tourism industry continues to flow and can change. Tourism development should also be done dynamically (Yeoman, 2010). Community-based tourism is a type of tourism that involves the community as a role in managing the potential of environmental tourism (Yusof et.al, 2012).

Community-based tourism opens new business opportunities that can be utilized by the community. Meeting the needs of tourists such as places to eat, lodging, rental of transportation and so forth can be a new business opportunity for the community in increasing family income. Management of tourism conducted directly by the community will provide confidence for those who obtained from the pocket of the bag of tourism activities that exist in the environment. Confidence and sense of Pocket to the tourism activities that exist in the environment. This selfconfidence has a significant influence on its performance in achieving a quality life. Increased self-confidence of people who grow in the tourism sector will have a positive impact on the quality of their lives (Yusof et.al, 2012).

Based on a summary of community-based enterprise development factors, researchers decreased several developing factors; Economic factors, social factors, environmental factors cultural factors, and political factors. And in this study I took a discussion of the developing factors; Economic Factor, where this factor to be studied into tourism reference as Ecotourism.

\section{METHOD}

There are two kinds of data as the material of analysis in research, that is primary data and secondary data (Kothari, 2004), researcher use two types of data where the primary data is collected by the researcher, and secondary data is supporting data obtained by the external researcher. The primary data obtained from the study of Community Based Tourism Research consists of two ways, namely through the distribution of questionnaires and field observations. Data obtained through questionnaires will be tabulated by means of frequency to produce objective data (Kothari, 2004). Tabulation of data by means of frequency also refers to similar research ever conducted by (Beny, 2015). In this study, researchers used a quantitative approach. The tabulated data will be analyzed quantitatively and associated with the data obtained by the researcher through the distribution of the questionnaire. Quantitative research methods can be interpreted as research methods based on positivism philosophy, used to examine the population or a particular sample.

Community-based tourism data obtained through the distribution of questionnaires obtained will be directly tabulated with SPSS and tourist attraction data obtained through field observations will be linked to community-based tourism data. The result of the analysis aims to answer the research problem, that is a description of community involvement and Iboih Beach Potential to be developed into communitybased tourism as a whole data analysis method in this research.

\section{RESULTS AND DISCUSSION}

Iboih Beach, Sabang is a tourist attraction that became the location in this study. The development of Iboih Beach is closely related to the community of Sabang, especially local residents Iboih sub district sukakarya. Iboih Beach is also a potential tourist attraction with a position that is not far from the center of Sabang City. Based on this research, the component of tourist attraction used is based on the theory (Jaafar et.al, 2015) which states the component of tourist attraction based on three components, namely attraction (attraction), access (accessibility), tourism facilities (amenities).

\section{1) Attractions and Objects}

Iboih beach, Sabang has a tourist attraction that is able to attract tourists to visit. The main reason tourists come to Iboih Beach because of the beauty will marine tourism is amazing, but the beach Iboih sabang has an attraction that is not just selling the beauty of nature alone. In addition to enjoying the natural beauty has to offer, other attractions that can be offered to tourists around Iboih Beach (Figure 1).
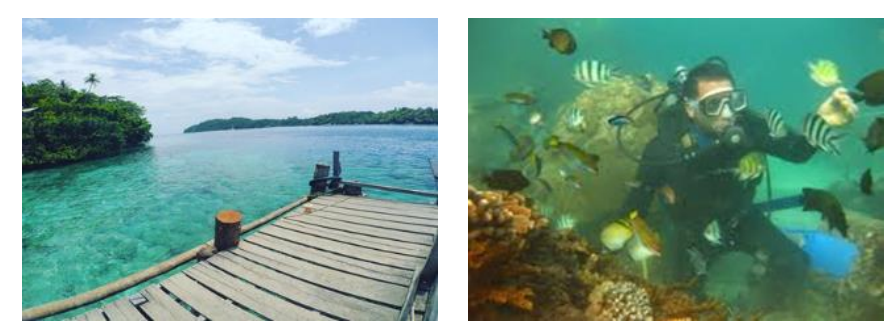

Figure 1: Great View on Iboih Beach

\section{- Scenery}

Iboih tourist area is a marine tourism destination that has a beautiful underwater scenery. This scenery can be enjoyed by diving or by boarding a boat with a glass base that has been available 
there. Exploration of the underwater beauty of Iboih can be continued to Rubiah Island.Rubiah Island is the main attraction for tourists because the island is the diversity of flora and fauna underwater is amazing (Figure 2).
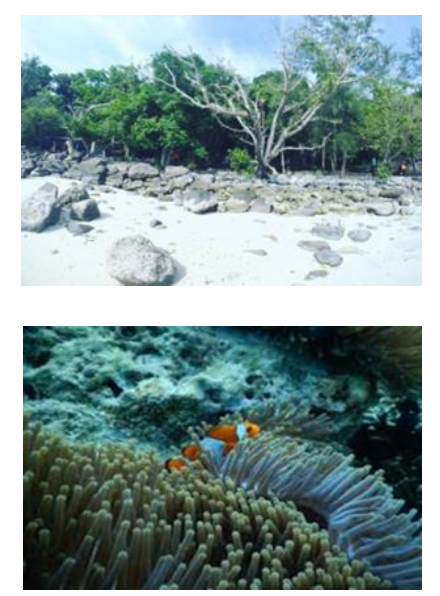

Figure 2. View of the Rubiah Island

- Interisting Activities dan Event Held

Apart from the beauty of the high sea, Iboih Beach also offers forests that attract tourists.But for the interesting activities to do on the beach this is a snorkeling activity, by enjoying the natural beauty under the sea (Figure 3). Sabang Marine Festival is an event organized by the central government of Sabang city, the event is expected to boost the number of tourist visits to Indonesia as well as making Sabang as a yacht destination destination in order to increase foreign exchange, as well as open employment to the community in the tourism sector.
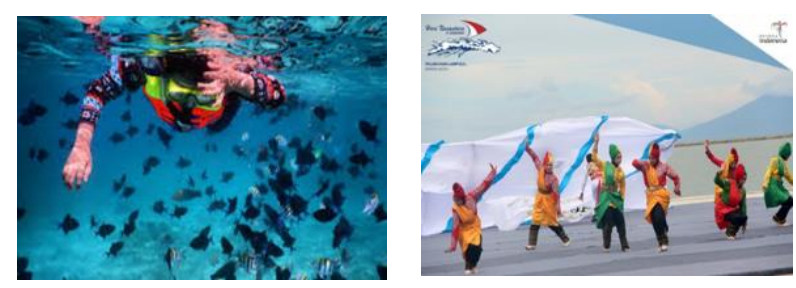

Figure 3. Interesting Activities

\section{2) Accessibility to Iboih Beach}

Access to Iboih Beach, can be started from Ulee Lheue Port, Aceh Province. Arriving there, can use the ferry to the Sea Port of Balohan, Sabang. Arriving at the Sea Port of Balohan, and can use public transportation to go to Iboih Beach. Sabang on Pulau Weh can be reached by ferry from Ulee Lheue Port in Banda City approximately 14 nautical miles. There are two fast fleet ships with 45 minutes of travel time and regular ferry with 90 minutes travel time (Figure 4).

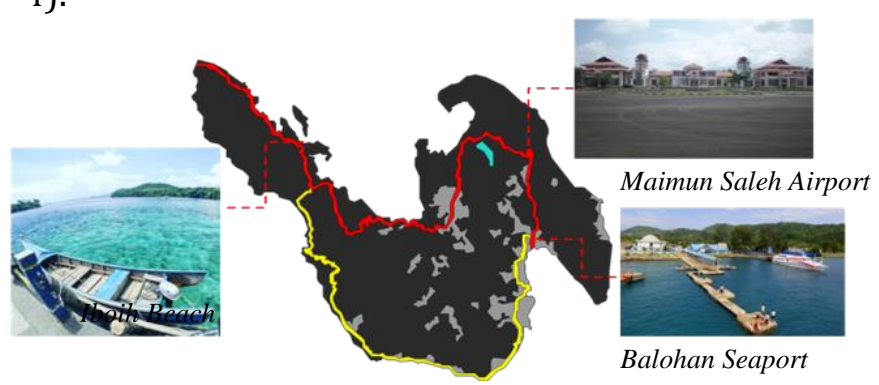

Fig 4: Acces to Iboih Beach from Maimun Saleh Airport

and Balohan Port

\section{3) Amenities on Iboih Beach}

There are 33 Lodging / Bungalow and 225 units, and the owner is mostly the local community of iboih beach. Public toilet available around the beach. Places to eat are directly managed by the local community so as to improve their economy.access achievement is very easy to be along the coast road iboih. There is a worship place located on the edge of Iboih Beach Road namely Tuha Babul Ibad Mosque (Figure 5).
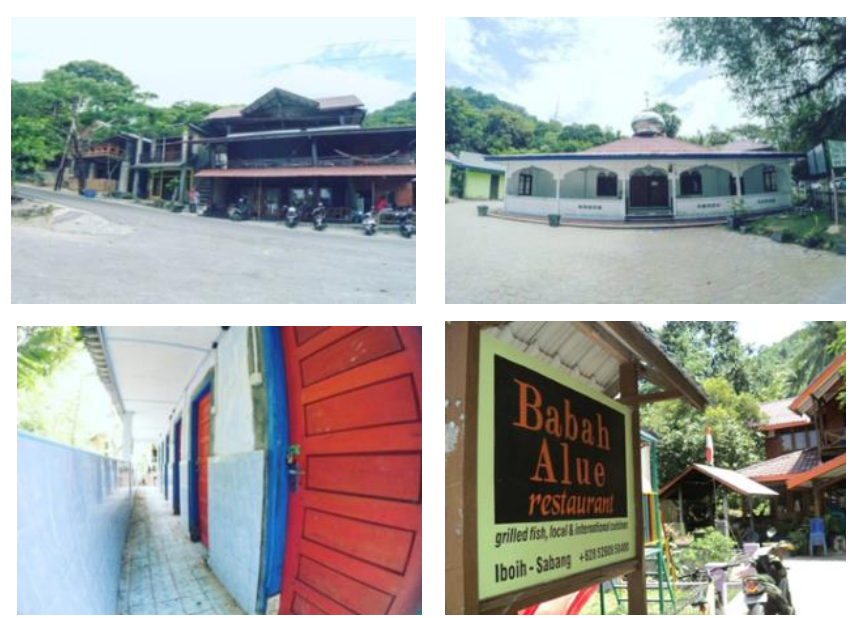

Figure 5. Facilities on Iboih Beach 


\section{4) Study of Community-Based Tourism in Economic Aspect}

Iboih Gampong economy is heavily influenced by tourism and trade. This makes one of the pre-eminent potentials of Gampong Iboih because most of the people's livelihood is from the tourists who come to camping Iboih. However, the existing potential has not fully increased the income and the need for adequate living due to the small income compared to the high prices of the market, where most of the daily necessities are still imported from Sabang city or outside Sabang city. So for that, it is necessary to improve the welfare of the community by conducting training, guidance, and coaching as well as providing business capital assistance for the community of the village of Saboih, Sabang. Based on the questionnaires distribution of 100 respondents related to the participation of the community in the development of the existing tourism on the beach of Iboih, Sabang and found the potential for the development of the beach of Iboih, Sabang into a community-based tourism, the researcher can summarize some of the findings in this study. The research findings are concluded by researchers based on economic aspects.

The result of this research is proved from SPSS 24 and the result is data to reinforce the result of research that has been done so that the influence of business opportunity in the field of tourism to increase family income, improvement of regional economic quality, society get maximum profit, and source of promising income Very influential on the development of community-based tourism in the economic aspects.

TABLE I. VARIABLE BUSINESS OPPORTUNITY IN THE FIELD OF

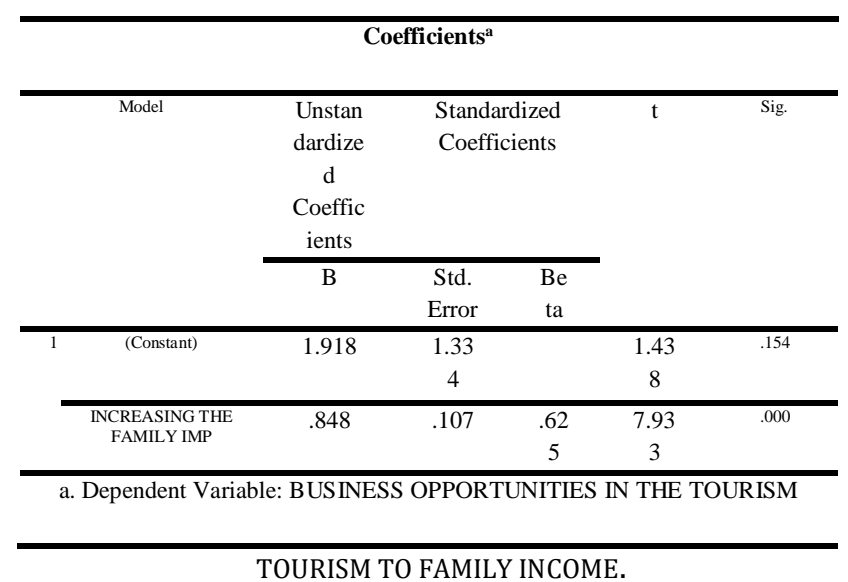

TABLE II. VARIABLE BUSINESS OPPORTUNITIES IN THE FIELD

\begin{tabular}{|c|c|c|c|c|c|c|}
\hline \multicolumn{7}{|c|}{ Coefficients $^{a}$} \\
\hline \multirow{2}{*}{\multicolumn{2}{|c|}{ Model }} & $\begin{array}{l}\text { Unstandar } \\
\text { dized }\end{array}$ & \multicolumn{2}{|c|}{$\begin{array}{l}\text { Standardized } \\
\text { Coefficients }\end{array}$} & \multirow[t]{2}{*}{$\mathrm{t}$} & \multirow[t]{2}{*}{ Sig. } \\
\hline & & B & $\begin{array}{l}\text { Std. } \\
\text { Error }\end{array}$ & $\begin{array}{l}\mathrm{Be} \\
\mathrm{ta}\end{array}$ & & \\
\hline 1 & (Constant) & 6.233 & 1.595 & & 3.908 & .000 \\
\hline & $\begin{array}{l}\text { INCREASING } \\
\text { THE } \\
\text { REGIONAL } \\
\text { ECONOMIC } \\
\text { QUALITY }\end{array}$ & .773 & .198 & $\begin{array}{l}.36 \\
7\end{array}$ & 3.904 & .000 \\
\hline & ependent V & BUSIN & $\mathrm{POF}$ & & $\mathrm{HE} \mathrm{T}$ & \\
\hline
\end{tabular}

OF TOURISM TO IMPROVE REGIONAL ECONOMIC QUALITY.

TABLE III. VARIABLE BUSINESS OPPORTUNITIES IN THE FIELD

\begin{tabular}{|c|c|c|c|c|c|c|}
\hline \multicolumn{7}{|c|}{ Coefficients $^{\mathrm{a}}$} \\
\hline & \multirow[t]{2}{*}{ Model } & \multirow{2}{*}{$\begin{array}{c}\begin{array}{c}\text { Unstandar } \\
\text { dized } \\
\text { Coefficient } \\
\text { s }\end{array} \\
\text { B }\end{array}$} & \multicolumn{2}{|c|}{$\begin{array}{l}\text { Standardized } \\
\text { Coefficients }\end{array}$} & \multirow[t]{2}{*}{$\mathrm{t}$} & \multirow[t]{2}{*}{ Sig. } \\
\hline & & & $\begin{array}{l}\text { Std. } \\
\text { Error }\end{array}$ & $\begin{array}{c}\text { Bet } \\
\text { a }\end{array}$ & & \\
\hline 1 & (Constant) & 2.045 & 1.268 & & 1.612 & .110 \\
\hline & $\begin{array}{l}\text { COMMUNITY } \\
\text { GETS } \\
\text { BENEFITS }\end{array}$ & .602 & .073 & $\begin{array}{c}.64 \\
0\end{array}$ & 8.249 & .000 \\
\hline
\end{tabular}

a. Dependent Variable: BUSINESS OPPORTUNITIES IN THE TOURISM

OF TOURISM TO THE PUBLIC GET THE MAXIMUM PROFIT.

TABLE IV. VARIABLE BUSINESS OPPORTUNITIES IN THE FIELD OF TOURISM BUSINESS TO THE SOURCE OF PROMISING FAMILY INCOME

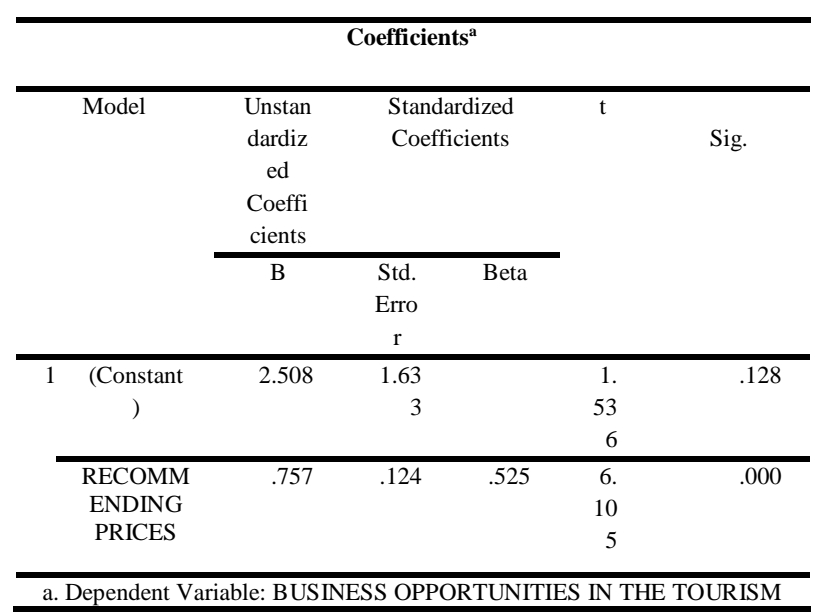


In the table coeficient we presented a variety of important and unimportant information, important information consists of variable names, value kostanta (Constant), $t$ value and significance value. Uncanny information is a standard error and a beta value in a standarized coeficient column. Not important because the standard error here is the standard error per variable, we do not need it because we just care about the standard error error problem. while the value of beta on standarized coefficient does not need to be discussed here because it will be useful if we do the analysis.

As we said before this table can be used to see the effect per variable. By the way, first by looking at the sig value. on each variable, if the sig value. its smaller than 0.05 then the conclusion influence the smaller sig. the more influential.

Where in the business opportunity variable in the field of tourism are the dependent variable and the variable increase the family income, improvement of the regional economic quality, the people get the maximum profit and the promising income source.

\section{CONCLUSION AND SUGGESTION}

For objects and attractions at iboih beach already have Attractions: natural beauty, diving, Rubiah Island scenes, snorkeling activities, and Sabang sea festival events. Accessibility: the location is easy to reach from the port of balohan to the beach of Iboih, and also from the pious maimun airport to iboih beach, the condition of the road to the beach of iboih is in good condition, and the availability of local transportation is easy to reach. Amenitas: Pretty well-located guesthouses on iboih beach, as well as easy to access places to eat, places of worship available, and public toilets available and easy to reach.

Result of Study of Community-Based Tourism in Economic Aspect: tourism at Iboih Beach is Community-based, the community is already directly involved in Tourism in Iboih Beach, economic benefits have also been felt by the people of Iboih Beach.

Based on the data that has been managed with SPSS 24, the results of each dependent variable and independent of the result are significantly smaller than 0.05 ie 0.000 so between the dependent and independent variables are related. The most dependent and dependent independent variables is the improvement of the Regional Economic Quality.

The role between society and government must be interconnected, and well established. Communication must be established in the development of coastal tourism iboih, Sabang. Government efforts should support the development of the tourism sector with the application of the principle of community-based tourism. Involve themselves and care about the potential of the surrounding tourism.

\section{ACKNOWLEDGMENT}

This research can be carried out with the support of the Departement of Architecture, Faculty of Engineering, Universitas Sumatera Utara.

\section{REFERENCES}

Aswita, Sarong, Sugianto. (2015). Evaluasi Kesesuaian Perairan Pantai Reupin Leye Padau Iboih Sebagai Ekowisata Bahari, Vol. 20, No. 1, April 2015, Banda Aceh: Syiah Kuala University.

Barkauskiene, K. and Vytautas, S. (2013). Ecotourism as an Integral Part of Sustainable Tourism Development. Jurnal Economics and Management, 18(3), ISSN 2029-9338.

Diniz, S. R., Falleiro, S. P. \& Barros, M. M. D. (2014). A Study of The Gendered Perception of Tourism in Coastal Goa, India. Journal of Researchers World Journal Of Arts, Science \& Commerce, 5(4), 160-171.

Fandeli, C., Mukhlison. (2000). Pengusahaan Ekowisata, Fakultas Kehutanan Universitas Gadjah Mada bekerjasama dengan Unit KSDA Daerah Istimewa Yogyakarta and Pustaka Pelajar, Yogyakarta.

Ferdinandus, Suryasih. (2014). Studi Pengembangan Wisata Bahari Untuk Meningkatkan Kunjungan Wisatawan di Pantai Natsepa Kota Ambon Provinsi Maluku, Vol. 2 No.2.

Goh, H. C. (2015). Nature And Community-Based Tourism (Cbt) For Poverty Alleviation: A Case Study Of Lower Kinabatangan, East Malaysia. Malaysian Journal of Society and Space, 11(3), pp. $42-52$.

Jaafar, M., Bakri, N. M. \& Rassolimanesh, S. M. (2015). Local Community and Tourism Depelopment: A Study of Rural Mountainous Destinations, Modern Applied Science, 9(8), 339-408.

Yoeti, Oka A. (1983). Pengantar Ilmu Pariwisata. Bandung, Angkasa. 
Marpaung, Beny O. Y. (2015). Suatu Kajian Ilmiah Mengenai Strategi Komunikasi Di Suatu Kampung, Program Studi Magister Teknik Arsitektur, Universitas Sumatera Utara, Medan.

Maulidasari, Yunus, Chan. (2015). Pengaruh Distinctive Capalities dan Integrated Marketing Communication Terhadap Citra Destinasi dan Dampak Pada Keputusan Berkunjung Pada Destinasi Wisata Maritim Pulau Weh, Vol. 4 No. 2, May 2015, Banda Aceh: Syah Kuala University.

Muhammad, M., Hamzah, A., Shaffril, H. A. M. D'Solva, J. L., Yassin, S. M., Samah, B. A. \& Tiraeyari, N. (2012). Involvement In Agro-Tourism Activities Among Fishermen Community In Two Selected Desa Wawasan Nelayan Villages In Malaysia. Asian Social Science, 8(13), 239-243.

Oktaviani, R. W., Suryana, R. N. (2006). Analisis Kepuasan Pengunjung Pengembangan Fasilitas Wisata Argo, Jurnal Agro Ekonomi, Volume 24 No.1.41-58.

Pane, Imam Faisal. (2016). Water Tower of Medan as a Character of the City Tourism, Procedia - Social and Behavioral Sciences 234,201 - 209.

Pendit, I Nyoman, S. (1994). Ilmu Pariwisata Sebuah Pengantar Perdana, Jakarta: Pradnya Paramita.

Pendit, Nyoman S. (2002). Ilmu Pariwisata, Jakarta, PT. Pradnya Paramita.

R, C Kothari. (2004). Research Methodology: Methods and Techniques, New Delhi: New Age Publisher.

Tuwo, A. (2011). Pengelolaan Ekowisata Pesisir dan Laut, Brilliant International, Surabaya.

Ginting, N., \& Wahid, J. (2015). Exploring Identity's Aspect of Continuity of Urban Heritage Tourism. Procedia-Social and Behavioral Sciences, 202, 234-241.

Yeoman, I. (2010).Tomorrow's Tourist: Fluid and Simple Identities. Journal of Globalization Studies, 1 (2), pp. 118-127.

Yusof, Y., Ibrahim, Y., Young, M. S., \& Amin, W. A. Ä. W. M. (2012). Community based tourism and quality of life. Review of Integrative Business and Economics Research, 1 (1), 336.

Zalikha. (2015). Peluang dan Tantangan Pelaksanaan Wisata di Kota Sabang, Vol. 22 No. 31, January-June 2015. 